324

\title{
球体貫入時に二液界面で発生する微小液滴の数と寸法の計測
}

\author{
米原 紀吉 ${ }^{\circ}$, 植村 知正 (関西大学), 井口 学 (北大院), 山内 慎 (関西大院)
}

\section{Number and Size of Droplets near Liquid-Liquid \\ Interface Generated by a Penetrating Sphere}

\begin{abstract}
Noriyoshi Yonehara, Tomomasa Uemura, Manabu Iguchi and Makoto Yamauchi
\end{abstract}
\begin{abstract}
This experiment was executed to investigate the deformation of liquid-liquid interface and making droplets by a penetrating sphere. This phenomenon will be related to problem of chemical reaction and contamination. Water and silicon oil under the room temperature are used for two kinds of liquid. An acrylic sphere or a brass sphere which is coated by paint is naturally released upon the oil layer respectively. The scene of penetration is captured by use of two cameras, that are high-speed video camera (500 frame/s) and high-grade video camera (30 frame/s, 1024-1024 pixel). The velocity of falling sphere and the numbers, positions, diameters, migration vectors of droplets are measured by image analyzing. These characteristics values (Table 1) are varied according to the velocity of a penetrating sphere. The time to generate droplets is measured about 0.1 second in this experiment.
\end{abstract}

Key words: Image Measurement, Liquid-Liquid Interface, Droplets

\section{1. ま えがき}

物体が二液界面を貫入する現象は化学反応や污 染, 混入問題と深い関係がある. 本研究はこの動的現象 を画像計測によって取得することを目的としている.前 報 1) 7)では物体が貫入の時に漏斗状に引き込まれる上 界面の体積, 表面積および物体付近の随伴流などを計測 した. 本報では貫入後に界面付近に発生する微小液滴に 注目し, その発生位置, 個数, 移動等の追跡を行う。こ れは貫入後の液滴発生時に二液の相対速度が意外に速 い現象であり，化学反応や混入に影響があると思われる からである.

\section{2. 実臨 方 法}

実験装置を図 1 に示す.内径 $174 \mathrm{~mm}$ の円筒に媣さ $300 \mathrm{~mm}$ の常温水を入れ, その上に厚さ $70 \mathrm{~mm}$ のシリコ ン油(動粘度 $500 \mathrm{cSt}$ )を置き, 油の表面上 $75 \mathrm{~mm}$ の位置 から単一球を自然落下させる.二液界面を球が通過して いく様子を側面から高速 (500 frame/s) と高解像度 (30 frame/s $1024 \times 1024 \mathrm{pixe1})$ の二台のビデオカメラで 同時撮影した. 高速度カメラは従来撮影が困難だった落 下球の速度や油が切断して油滴が形成していく様子の
ために用いる.また高解像度カメラは生成した微粒子の 正確な計測用に必要であった。この際, 水中に発生する 微小な油滴を撮影するために, 油に染料を加え，照明と してバックライトを用いた.

球体は $\phi 14.9 \mathrm{~mm}$ のアクリル(比重 1.22$)$ と, $\phi$ $9.6 \mathrm{~mm}$ (比重 8.46)の黄銅としている. 球の表面性状を同 ビにするため,市販の合成樹脂エナメル叙料を塗布した。

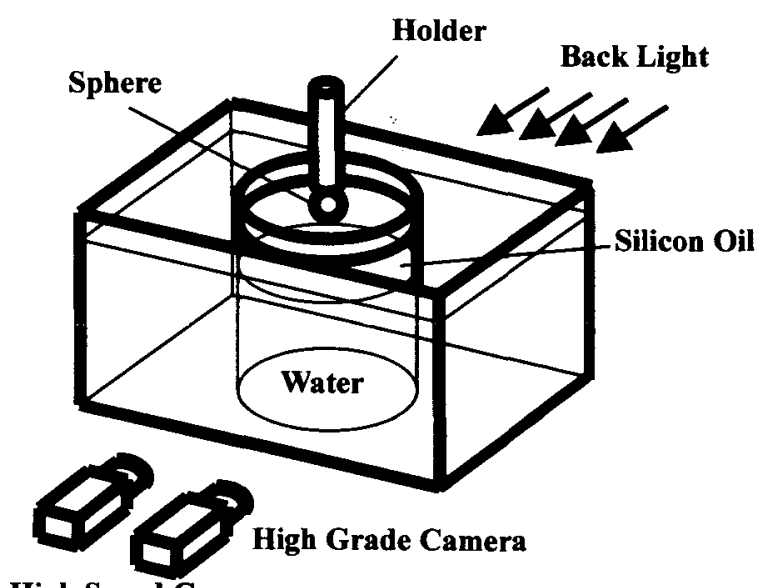

High Speed Camera

Fig.1 Experimental setup 


\section{3. 実 験 結 果 と 考 察}

落下球が濃紺の油と透明な水の界面を通過していく 様子として, 高解像度カメラで撮影した画像の一部を図 2 に示す. 図中に示した数字は球の中心が界面を通過す る時からの経過時間 (秒) をフレーム数を用いて表示し ている. 図 2 (a) はアクリル球の場合で, 静かに水中 を落下していく，油の糸が細くなり，やがて切断し，こ の例では大小 5 個の油滴が発生した. 油の糸が切断され て油滴形成の所要時間はわずか 0.1 秒である.しかし， 油滴の動きは緩やかで密度差によってゆっくり上昇し ていく. 最初の油滴が界面へ戻るのは約 3 秒である. そ して 5 秒以内には大きい油滴も界面に戻る.

図 2(b) 獚銅球を落下させた場合で球が油膜平面 を突き破った後は図 2(b)の左端に示すように球の後半 部にリング状の油が形成されているのがわかった。その 後球の落下につれて油層本体との慗がりは細くなり, 速 い球の後流のためかき乱されている様子が撮影されて
いる.曲がりくねった糸状の少し太い部分を核として図 2(b)の例では大小 11 個の油滴が発生した (約 0.2 秒). 発生した油滴が界面へ初めて戻るのは球貫入後 4.1 秒 である，そしてこの画面の油滴がすべて戻るのは約 5 秒である.この画面下方にも少しの油滴発生がひきつづ いて起こっていたが, 球と油層間の慗がりが最初に切れ る界面下領域を対象としているので今回は考虑しない こととしている.

図 2 の画像から，球体が界面を貫入通過すことによ って引き起こされる様態は混合や化学変化を考えてい く上で興味あることがうかがえる.得られた画像から主 として球体貫入直後の界面付近に限定して,いくつかの 計測結果を示す.

\section{3-1 球 速 度}

高速度カメラによって撮影された画像から経過時 間に対する球の位置と速度を図 3 に示す. 本報では油滴

(a)

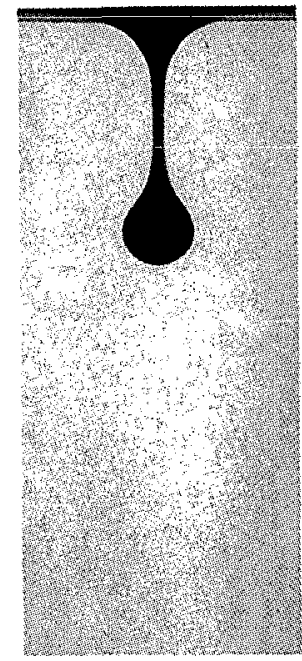

$76 / 30 \mathrm{~s}$

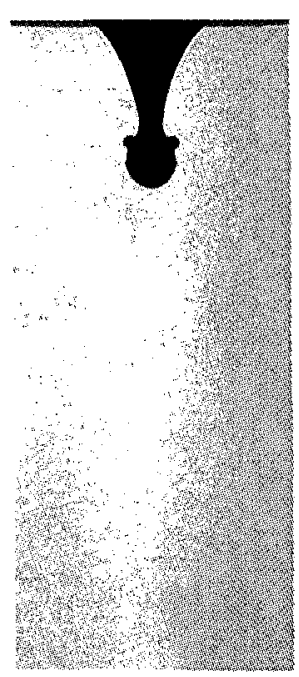

(b) $3 / 30 \mathrm{~s}$

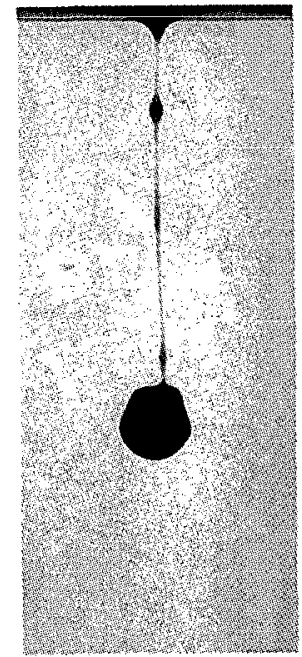

$84 / 30$ s

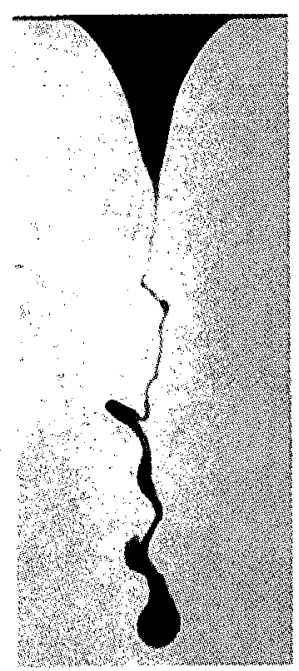

$13 / 30 \mathrm{~s}$

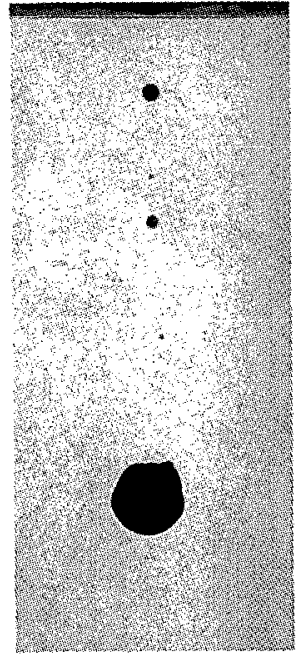

$87 / 30$ s

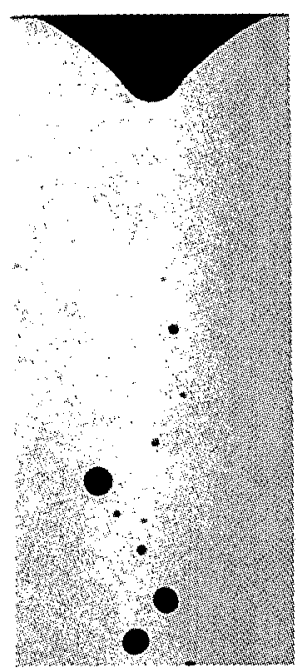

$20 / 30 \mathrm{~s}$

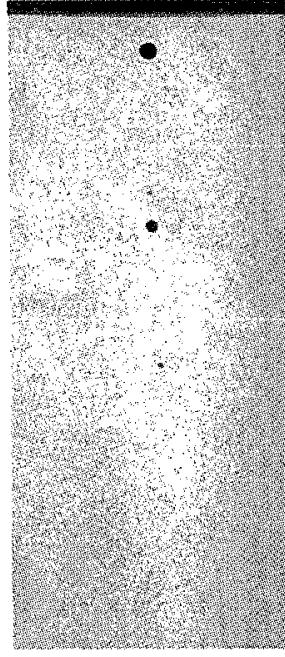

$95 / 30 \mathrm{~s}$

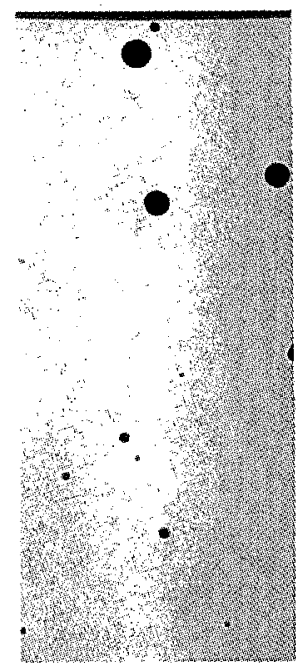

$124 / 30 \mathrm{~s}$
Acrylic

$\phi 14.9$

Brass

$\phi 9.6$

Fig.2 Behavior of silicone droplets generated by a penetrating sphere 
の撮影に重点を置くため, 高濃度な染色油を用いたので 球だけ油の中から抽出はできず, 油層先端部を球の速度 とみなしている ${ }^{3)}$. 本報告の図はす心゙て長さや速度は球 の直径Dを単位とし，また界面を球の中心が通る時刻を 零としている.比重の小さいアクリル球は界面付近で停 滞気味であることがわかる，そして直径の 15 倍付近の 深さで少し減速がみられるのは終端速度での少し左方 向への球の片振れ (0.72D) を起こしているからである. これは付着した油の影響と思われる。

それに対して,比重の大きい黄銅球の場合は界面抵 抗の影響をあまり受けることなく貫入通過しているこ とを示し, 終端速度に末だ入らない状態までを捉えてい る.

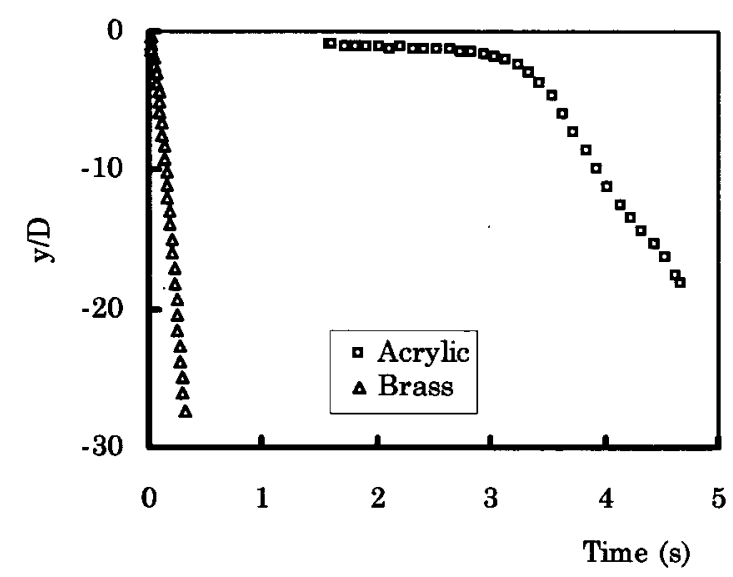

(a) Trajectory of sphere

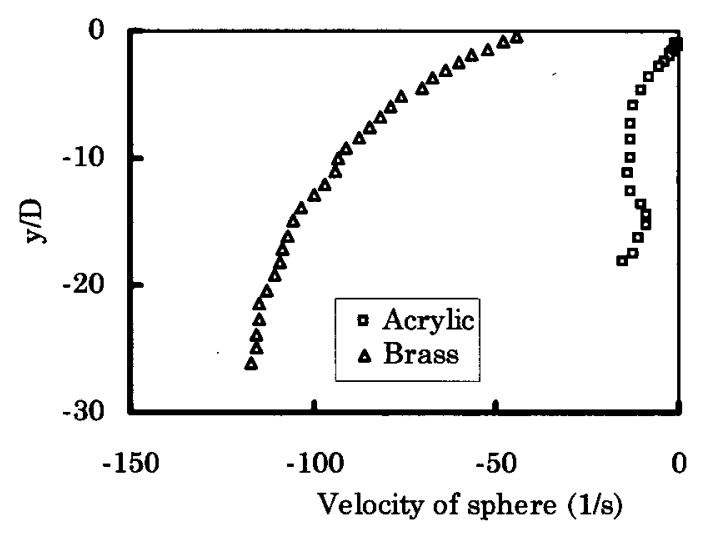

(b) Velocity of sphere

Fig. 3 The velocity of falling sphere

3-2 界面付近での油滴発生 高解像度カメラで界面直下を撮影した画像の中か ら, 最初に球形化したときの油滴の状態を計測する. 図 2 (a) の $87 / 30 \mathrm{~s}$, 図2（b）の 20/30 s を用いて油滴 の位置と寸法, そして発生油滴の体積, 表面積を求める. 画像上で油滴の境界位置を求めるのは, 綐と横の二方向 の直線と交わる三点以上の点から円とみなした油滴の
中心座標と直径を算出する手法 ${ }^{8)}$ を用いている. 油滴 発生直後の二画面から油滴の移動速度も求めて,これら の計測結果を図 4 に示す. ○印は貫入速度が $8.9 \mathrm{~mm} / \mathrm{s}$ で 発生した場合であり，○印は $419 \mathrm{~mm} / \mathrm{s}$ の場合である. なお図 4 の油滴の直径は軸とは関係なく大小だけと移 動速度を描いている。

貫入速度の小さい場合は界面付近に 3 個取得され た. それに対して, 貫入速度の大きい場合は深い場所で 多数の大きな油滴が発生し，この画面から 10 個の油滴 を捕捉することができた. 原画像では肉眼で視認される $\phi 1 \mathrm{~mm}$ 以下の微粒子は今回での処理では捕捉できなか ১た.

つぎに発生直後の油滴の速度べクトルをみると,い ずれも球の落下方向に向かっている.いずれも油滴発生 直後は落下球の後流の影響を受けており, 速度の速い 印は乱れによって水平方向の速度成分をもつことを示 している. 肉眼の奏体観察では, 球が水中を落下した後 では螺旋状に回る油滴も見られ, 油滴の動きを三次元的 に取り扱う必要があろう。

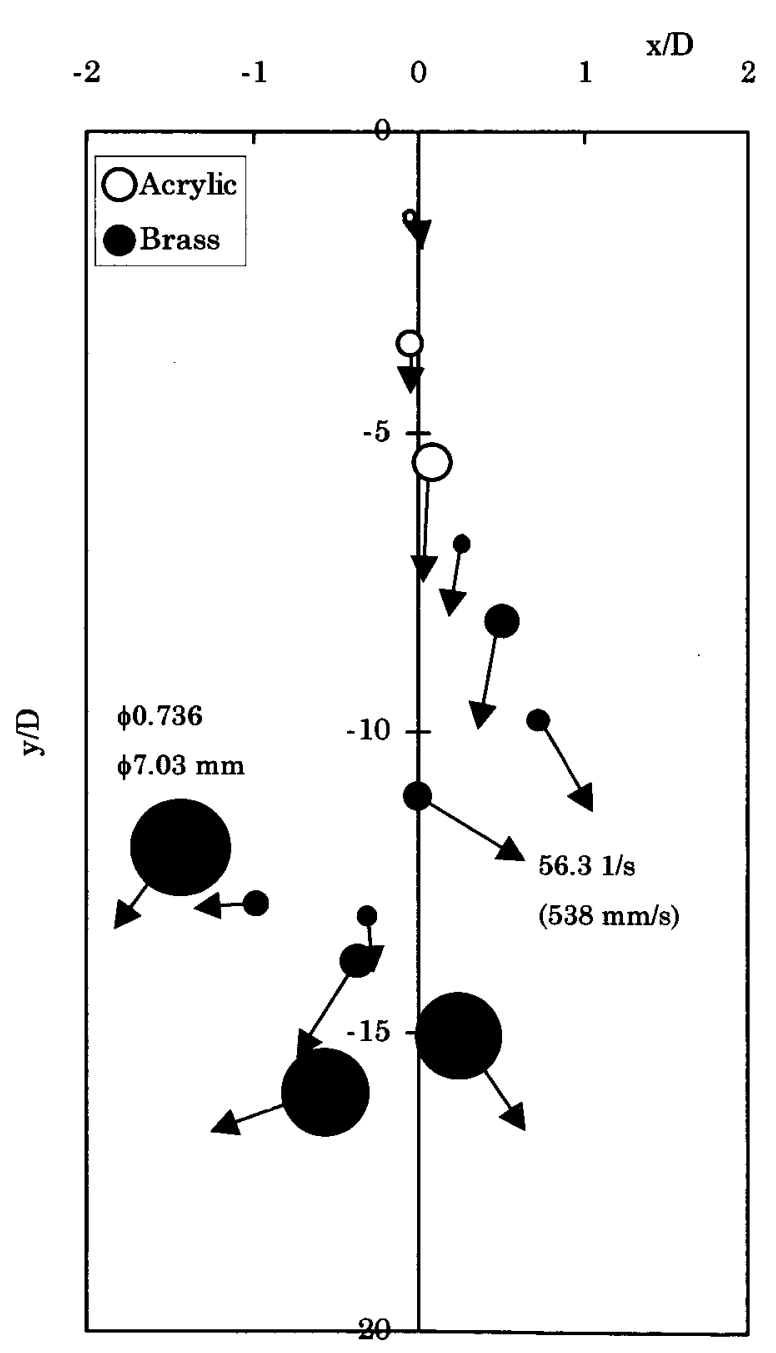

Fig. 4 The position and velocity of generated droplets 
Table 1. Measurement values of droplets

\begin{tabular}{|c|c|c|}
\hline Sphere & $\phi 15$ Acrylic & $\phi 10$ Brass \\
\hline Velocity $(\mathrm{mm} / \mathrm{Ds}),(\mathrm{mm} / \mathrm{s})$ & $-0.6,(-8.9)$ & $-43.8,(-419)$ \\
\hline Number of Droplets & 3 & 10 \\
\hline Location $(\mathrm{mm} / \mathrm{D})$ & $\mathrm{x} ;-0.030 \sim 0.093$ & $\mathrm{x} ;-1.48 \sim 0.73$ \\
& $\mathrm{y} ;-1.46 \sim-5.47$ & $\mathrm{y} ;-6.80 \sim-16.14$ \\
\hline Diameter $(\mathrm{mm} / \mathrm{D})$ & $0.077 \sim 0.29$ & $0.11 \sim 0.74$ \\
\hline Velocity of Droplets $(\mathrm{mm} / \mathrm{Ds})$ & $2.3 \sim 56$ & $31 \sim 51$ \\
\hline Total Volume $\left(\mathrm{mm}^{3} / \mathrm{W}\right)$ & 0.031 & 1.0 \\
\hline Total Surface $\left(\mathrm{mm}^{2} / \mathrm{A}\right)$ & 0.12 & 1.7 \\
\hline Maximum Volume of Oil Interface Deformation $\left(\mathrm{mm}^{3} / \mathrm{W}\right)$ & 14.3 & 33.4 \\
\hline Maximum surface Area of oil Interface Deformation $\left(\mathrm{mm}^{2} / \mathrm{A}\right)$ & 3.52 & 8.46 \\
\hline
\end{tabular}

D : Diameter of sphere, $W$ : Volume of sphere, A : Surface of sphere

\section{$3-3$ 油 滴 $の$ 計 測 值}

界面付近で発生した直後の油滴を画像計測した結 果をまとめて表 1 に示す。ここで球の速度とは界面下 1 直径分の位㯰に球の中心があるときの球の落下速度と している. 貫入速度の違いによって, 油滴の発生個数, 発生位置とその広がり, 大きさ, 浮遊速度等異なってい ることを示している.

参考のために, 表 1 の下端の欄には貫入球によって 界面が下の水中一漏斗状に引き込まれるときの最大体 積と表面積を示している ${ }^{2)}$. 発生油滴に対してオーダが 異なる大きさをもっているが，これは液一液界面全体の いわば移動動作であり,短時閒で微粒子が発生する現象 とはまったく変形動作が異なるものである.

\section{4. 結言}

常温の水とシリコン油を用いた二液界面に, 表面は 同一の塗装を施した二種の単一球をそれぞれ自然落下 させて, 界面下の水中で発生する微小な油滴を高速度 (500 frame/s) と高解像度 $(1024 \times 1024 \mathrm{pixel})$ の 二台のカメラで同時撮影した. その結果, 界面付近での 油滴発生の様子, 個数, 位置, 大きさ, 移動を計测し, 画面上の油滴のもつ体積や表面積を算出することがで きた．貫入速度の違いによって異なる結果（表 1) を示 している. また糸状に伸びた油から油滴が発生する所要 時間は 0.1 秒であった。

\section{参考文献}

(1) M. Iguchi, K. Okita, F.Yamamoto, and T. Uemura, Behavior of a Solid Sphere passing through the Interface between Stratified Two Liquid Layers, J. of Flow Visualization and Image Proceeding, vol. 2, pp. 375 391, 1995.

（2）米原, 山内, 植村, 重栖, 湯口, 物体貫入時の液 液界面形状の画像計測, 日本鉄鋼協会講演論文集, vol.10, No.5, p.1030, 1997.

（3）山内，植村，重栖，湯口，物体貫入時の液 - 液界面 の境界検出（不鮮明な境界の検出と形状計測），可 視化情報, vol. 17, Suppl. No.2, p.225 228, 1997.

（4）米原, 植村, 山内, 物体貫入時の液 - 液界面現象の 画像計測，可視化情報，vol. 18, Suppl. No.1, p.125 128, 1998.

(5) 米原, 植村, 山内, 井口球体貫入時の液・液界面に 生じる随伴流れの計測, 機械学会関西支部 256 回 講演論文集, p.6-13 6-14,1998.

(6) N.Yonehara,T. Uemura, M. Iguchi, M. Yamauchi. Image Measurement for Analyzing LiquidLiquid Interface Phenomena Caused by a Penetrating Sphere. Proc. of the 11th Int. Symp. on Transport Phenomena, pp.273 277,1998.

(7) N.Yonehara, T.Uemura, M.Iguchi, M.Ymauchi, Flow Induced by a Sphere Penetrating LiquidLiquid Interface, Proc. VSJ-SPIE98, Yokohama, pp.260 261,1998.

(8) 郷原, 植村, 円形パターンの高速検出と応用, 可視 化情報，vol. 18, Suppl. No.1, p.193 196, 1998. 